\title{
PENGARUH DOSIS DAN WAKTU APLIKASI PUPUK UREA DALAM MENINGKATKAN PERTUMBUHAN DAN HASIL JAGUNG (Zea mays, L.) PIONEER 27
}

\author{
Diana Saragih, Herawati Hamim \& Niar Nurmauli \\ Jurusan Agroteknologi, Fakultas Pertanian Universitas Lampung \\ Jl.Prof. Soemantri Brodjonegoro, No.1 Bandar Lampung 35145 \\ E-mail:Manihuruk_dianaa@yahoo.com)
}

\begin{abstract}
ABSTRAK
Penelitian ini bertujuan untuk mengetahui (1) waktu aplikasi urea yang diberikan secara bertahap dalam meningkatkan pertumbuhan dan hasil jagung hibrida Pioneer 27, (2) dosis pupuk urea yang optimum dalam meningkatkan pertumbuhan dan hasil jagung Pioneer 27, dan (3) interaksi antara dosis dan waktu aplikasi pupuk urea dalam meningkatkan pertumbuhan dan hasil jagung Pioneer 27. Penelitian dilaksanakan dari bulan November 2011 sampai Februari 2012 di Kebun Percobaan Politeknik Negeri Lampung. Rancangan percobaan yang digunakan adalah rancangan kelompok teracak sempurna (RKTS) dengan dua faktor. Faktor pertama adalah pemberian dosis pupuk urea dengan $4 \operatorname{taraf}\left(100 \mathrm{~kg}\right.$ urea/ha $\left(\mathrm{d}_{1}\right), 200 \mathrm{~kg}$ urea $/ \mathrm{ha}\left(\mathrm{d}_{2}\right)$, $300 \mathrm{~kg}$ urea $/ \mathrm{ha}\left(\mathrm{d}_{3}\right)$, dan $400 \mathrm{~kg}$ urea $/ \mathrm{ha}\left(\mathrm{d}_{4}\right)$, sedangkan faktor kedua adalah waktu aplikasi pemberian pupuk urea dengan 3 taraf (2 kali pada 1 MST dan awal berbunga ( $\left.\mathrm{t}_{1}\right)$, 3 kali pada 1 MST, 3 MST, dan awal berbunga $\left(\mathrm{t}_{2}\right)$, dan 4 kali pada 1 MST, 2 MST, 3 MST, dan awal berbunga ( $\left.\mathrm{t}_{3}\right)$ ). Keragaman diuji dengan uji Bartlett, sifat kemenambahan data diuji dengan uji Tukey, kemudian dilakukan analisis ragam, dan dilanjutkan dengan uji ortogonal dan ortogonal polinomial pada taraf nyata $5 \%$. Hasil penelitian menunjukkan bahwa (1) waktu aplikasi urea yang diberikan secara bertahap hanya dapat meningkatkan tinggi tanaman. Pemberian 3 dan 4 kali lebih baik dibandingkan pemberian $2 \mathrm{kali}$, (2) pemberian dosis $285 \mathrm{~kg}$ urea/ha mampu meningkatkan bobot kering berangkasan, (3) pemberian dosis $100 \mathrm{~kg}$ urea/ha dengan aplikasi $2 \mathrm{kali}$ (1 MST dan awal berbunga) sudah meningkatkan hasil jagung sebesar 10,65 t/ha.
\end{abstract}

Kata Kunci : Dosis urea, jagung, waktu aplikasi urea

\section{PENDAHULUAN}

Jagung merupakan komoditas pangan yang memiliki potensi besar untuk kepentingan industri pangan, pakan, dan biofuel. Selain untuk konsumsi manusia, jagung juga dimanfaatkan sebagai pakan ternak unggas dan ruminansia.

Di negara maju, sari pati jagung diolah menjadi gula rendah kalori dan ampasnya diproses kembali untuk menghasilkan alkohol dan monosodium glutamat, dengan semakin berkembangnya industri pengolahan pangan di Indonesia maka kebutuhan akan konsumsi jagung di Indonesia terus meningkat. Hal ini didasarkan pada semakin meningkatnya tingkat konsumsi perkapita per tahun dan semakin meningkatnya jumlah penduduk Indonesia.

Petani jagung biasa memupuk tanamannya dengan menggunakan pupuk urea, karena kandungan unsur Nitrogen $(\mathrm{N})$ dalam pupuk cukup tinggi yaitu 46 $\%$. Namun dalam praktiknya, cara pemberian dan waktu aplikasi pupuk urea masih kurang benar. Petani jagung lebih memilih pemberian urea pada saat tanam dibandingkan dengan pemberian urea secara bertahap dengan alasan untuk menghemat tenaga kerja.

Koswara (1983) mengatakan bahwa tanaman jagung mengambil $\mathrm{N}$ sepanjang hidupnya. Nitrogen diserap tanaman selama masa pertumbuhan sampai pematangan biji, sehingga tanaman ini menghendaki tersedianya $\mathrm{N}$ secara terus menerus pada semua stadia pertumbuhan sampai pembentukan biji. Pemberian pupuk yang tepat selama pertumbuhan tanaman jagung dapat meningkatkan hasil jagung. Sifat pupuk N umumnya mobil, maka untuk mengurangi kehilangan $\mathrm{N}$ karena pencucian maupun penguapan, sebaiknya $\mathrm{N}$ diberikan secara bertahap (Lingga dan Marsono, 2008).

Mengingat pupuk urea merupakan faktor pembatas dalam pertumbuhan dan hasil jagung. Maka dilakukan penelitian yang bertujuan (1) untuk mengetahui waktu aplikasi urea yang diberikan secara bertahap dalam meningkatkan pertumbuhan dan hasil jagung hibrida Pioneer 27, (2) mengetahui dosis pupuk urea yang optimum dalam meningkatkan pertumbuhan dan hasil jagung Pioneer 27, dan (3) mengetahui interaksi antara 
dosis dan waktu aplikasi pupuk urea dalam meningkatkan pertumbuhan dan hasil jagung Pioneer 27.

\section{BAHAN DAN METODE}

Penelitian ini dilaksanakan dari bulan November 2011 sampai Februari 2012 di Kebun Percobaan Politeknik Negeri Lampung. Bahan-bahan yang digunakan adalah benih jagung hibrida varietas Pioneer 27, pupuk urea, pupuk SP-36, pupuk $\mathrm{KCl}$, insektisida Fastac 15 EC, Furadan 3G, dan fungisida Ridomil 35 D.

Rancangan perlakuan disusun secara faktorial (4x3) dalam rancangan kelompok teracak sempurna (RKTS) dengan 3 ulangan. Faktor pertama adalah dosis pupuk urea yang terdiri dari $100 \mathrm{~kg}^{\mathrm{k}}$ urea ha-1 $\left(\mathrm{d}_{1}\right), 200$ kg urea ha-1 $\left(\mathrm{d}_{2}\right), 300 \mathrm{~kg}$ urea ha-1 $\left(\mathrm{d}_{3}\right)$, dan $400 \mathrm{~kg}$ urea $\mathrm{ha}^{-1}\left(\mathrm{~d}_{4}\right)$. Faktor kedua adalah waktu aplikasi pupuk urea yang diberikan secara bertahap pada jagung, yaitu sebanyak 2 kali pada 1 MST dan awal berbunga $\left(\mathrm{t}_{1}\right)$, sebanyak 3 kali yaitu pada 1 MST, 3 MST, dan awal berbunga $\left(\mathrm{t}_{2}\right)$, dan sebanyak 4 kali yaitu pada 1 MST, 2 MST, 3 MST, dan awal berbunga $\left(\mathrm{t}_{3}\right)$.

Penanaman dilakukan dengan sistem tugal dengan kedalaman 3-5 cm dan jarak tanam 75 x $25 \mathrm{~cm}$. Pemupukan dilakukan sesuai dengan dosis yang diberikan sesuai perlakuan, sedangkan untuk pupuk SP$36\left(150 \mathrm{~kg} \mathrm{ha}^{-1}\right), \mathrm{KCl}\left(100 \mathrm{~kg} \mathrm{ha}^{-1}\right)$ pada saat tanaman berumur 1 MST. Pengendalian hama dan penyakit dilakukan setiap seminggu sekali. Panen dilakukan apabila telah menunjukkan ciri matang panen.

\section{HASIL DAN PEMBAHASAN}

Hasil penelitian menunjukkan bahwa waktu aplikasi pupuk urea tidak berpengaruh pada pertumbuhan tanaman jagung kecuali untuk variabel tinggi tanaman (Tabel 1). Hal ini diduga karena penambahan tinggi tanaman yang terjadi bukanlah penambahan jumlah ruas batang, melainkan penambahan panjang ruas-ruas batang sehingga akan menghasilkan jumlah daun yang sama. Sebagaimana yang dikemukakan oleh Gardner, Peace, dan Michell (1991), batang tersusun dari ruas yang merentang diantara buku-buku batang tempat duduknya daun, sehingga jumlah buku dan ruas sama dengan jumlah daun.

Hasil penelitian menunjukkan bahwa interaksi dosis dan waktu aplikasi pupuk urea mampu meningkatkan bobot kering berangkasan (Tabel 1). Dosis pupuk urea optimum sebesar $285 \mathrm{~kg}$ urea/ha yang diaplikasikan sebanyak 4 kali lebih baik dibandingkan aplikasi urea sebanyak 3 kali (Gambar 1). Hal ini diduga pemberian pupuk urea sebanyak 4 kali dapat mencegah kehilangan $\mathrm{N}$ baik melalui proses pencucian dan penguapan. Adanya interval aplikasi pupuk urea maka unsur hara yang diaplikasikan dapat tersedia bagi tanaman sehingga kebutuhan unsur $\mathrm{N}$ bagi tanaman terpenuhi, dengan tersedianya unsur hara dalam jumlah yang cukup pada saat pertumbuhan vegetatif, maka fotosintesis akan berjalan aktif dan protein yang terbentuk akan semakin banyak.

Menurut Suwardi dan Roy (2009), pemberian N yang semakin tinggi berpengaruh terhadap tinggi tanaman pada fase V9 (42 hst) dan bobot kering tanaman. Semakin besar pemberian N , tinggi tanaman dan bobot kering tanaman semakin besar. Hal ini berhubungan dengan kecukupan hara yang diberikan diserap oleh tanaman. Pada awal pertumbuhan tanaman jagung membutuhkan unsur nitrogen dalam jumlah yang banyak untuk ditujukan ke pertumbuhan vegetatif awal.

Hasil penelitian menunjukkan bahwa dosis dan waktu aplikasi pupuk urea tidak berpengaruh pada bobot 100 butir (Tabel 1). Hal ini diduga lebih disebabkan adanya pengaruh genetik dari tanaman jagung itu sendiri. Meskipun bobot 100 butir tergolong tinggi melebihi dari deskripsi tanaman jagung yaitu \pm 30 gram 100 butir $^{-1}$ (Tabel 9). Walaupun dosis dan waktu aplikasi pupuk urea tidak berpengaruh pada bobot 100 butir, tetapi berpengaruh pada hasil jagung per hektar (Tabel 1). Hasil jagung meningkat diduga karena respon tanaman jagung hibrida P27 yang tergolong sangat respon terhadap pemupukan nitrogen khususnya urea yang dapat menyebabkan meningkatnya jumlah bobot biji per tongkol. Hasil jagung per hektar menunjukkan adanya hubungan positif antara hasil jagung per hektar dengan diameter tongkol (Tabel 2). Ini berarti semakin besar diameter tongkol maka hasil per hektar akan semakin meningkat. Hal ini sejalan dengan penelitian yang dilakukan Bara dan Chozin (2009), mengatakan bahwa semakin lebar diameter tongkol, maka biji yang terdapat pada tongkol tersebut semakin banyak sehingga bobot biji yang terdapat pada tongkol juga semakin besar sehingga hasil semakin besar.

Setiap penambahan dosis $1 \mathrm{~kg}$ urea ha ${ }^{-1}$ akan meningkatkan hasil jagung per hektar sebesar 0,005 t ha $^{-1}$ untuk aplikasi urea sebanyak 3 kali ( 1 MST, 3 MST dan awal berbunga) dan 4 kali (1 MST, 3 MST, 4 MST, dan awal berbunga) dan pada dosis $400 \mathrm{~kg}$ urea ha ${ }^{-1}$ yaitu 10,93 $\mathrm{t} \mathrm{ha}^{-1}$ dan 10,98 $\mathrm{t} \mathrm{ha}^{-1}$. Pada dosis $100 \mathrm{~kg}$ urea ha ${ }^{-1}$ dengan aplikasi sebanyak 2 kali (1 MST dan awal berbunga) memberikan hasil jagung sebesar 10,65 $\mathrm{t} \mathrm{ha}^{-1}$ (Gambar 2). Menurut Suwardi dan Roy (2009), mengatakan bahwa pemberian pupuk Nitrogen dengan pemberian dua kali sudah memberikan hasil lebih tinggi dengan takaran $100 \mathrm{~kg}$ urea ha- ${ }^{-1}$. Pemberian hara $\mathrm{N}$ yang sesuai kebutuhan tanaman baik jumlah dan waktu 
Tabel 1. Pengaruh dosis dan waktu aplikasi urea dalam meningkatkan pertumbuhan dan hasil jagung Pioneer 27

\begin{tabular}{|c|c|c|c|c|c|c|c|c|}
\hline \multirow[b]{2}{*}{ Perbandingan } & \multicolumn{8}{|c|}{ F-hit (Signifikansi) } \\
\hline & $\begin{array}{l}\text { TT } \\
(\mathrm{cm})\end{array}$ & $\begin{array}{c}\text { JD } \\
\text { (helai) }\end{array}$ & $\begin{array}{c}\text { BKB } \\
(\mathrm{g})\end{array}$ & $\begin{array}{l}\text { PT } \\
(\mathrm{cm})\end{array}$ & $\begin{array}{l}\text { DT } \\
(\mathrm{cm})\end{array}$ & $\begin{array}{c}\text { B100 } \\
\text { (g) }\end{array}$ & $\begin{array}{c}\text { BBPT } \\
(\mathrm{g})\end{array}$ & $\begin{array}{l}\text { Hasil } \\
\text { (t/ha) }\end{array}$ \\
\hline \multicolumn{9}{|l|}{ Dosis (d) } \\
\hline $\mathrm{C}_{1}:$ Linier & $3,99^{\operatorname{tn}}$ & $0,82^{\mathrm{tn}}$ & $3,09^{\mathrm{tn}}$ & $1,51^{\mathrm{tn}}$ & $2,66^{\mathrm{tn}}$ & $0,42^{\mathrm{tn}}$ & $1,86^{\mathrm{tn}}$ & $8,26^{*}$ \\
\hline $\mathrm{C}_{2}:$ Kuadratik & $0,01^{\mathrm{tn}}$ & $1,47^{\mathrm{tn}}$ & $4,77^{*}$ & $2,06^{\mathrm{tn}}$ & $2,80^{\operatorname{tn}}$ & $2,52^{\mathrm{tn}}$ & $0,06^{\mathrm{tn}}$ & $12,8^{*}$ \\
\hline \multicolumn{9}{|l|}{ Waktu aplikasi (t) } \\
\hline $\mathrm{C}_{3}: \mathrm{t}_{1} \mathrm{vs}_{2} \mathrm{t}_{3}$ & $\begin{array}{l}5,52^{*} \\
(0,73)\end{array}$ & $0,08^{\text {tn }}$ & $1,39^{\text {tn }}$ & $4,22^{\operatorname{tn}}$ & $0,33^{\operatorname{tn}}$ & $0,56^{\mathrm{tn}}$ & $0,04^{\text {tn }}$ & $1,51^{\text {tn }}$ \\
\hline $\mathrm{C}_{4}: \mathrm{t}_{2} \mathrm{vs}_{3}$ & $0,40^{\text {tn }}$ & $0,25^{\mathrm{tn}}$ & $1,21^{\mathrm{tn}}$ & $1,11^{\mathrm{tn}}$ & $1,42^{\mathrm{tn}}$ & $0,24^{\mathrm{tn}}$ & $0,14^{\mathrm{tn}}$ & $0,01^{\text {tn }}$ \\
\hline \multicolumn{9}{|l|}{ Interaksi } \\
\hline $\mathrm{C}_{5}: \mathrm{C}_{1} \mathrm{X} \mathrm{C}_{3}$ & $1,56^{\mathrm{tn}}$ & $0,80^{\operatorname{tn}}$ & $1,50^{\operatorname{tn}}$ & $0,23^{\mathrm{tn}}$ & $0,72^{\mathrm{tn}}$ & $2,79^{\mathrm{tn}}$ & $2,12^{\operatorname{tn}}$ & $2,37^{\text {tn }}$ \\
\hline $\mathrm{C}_{6}: \mathrm{C}_{1} \mathrm{XC}_{4}$ & $0,08^{\mathrm{tn}}$ & $0,05^{\mathrm{tn}}$ & $1,83^{\mathrm{tn}}$ & $0,55^{\text {tn }}$ & $0,69^{\mathrm{tn}}$ & $1,18^{\mathrm{tn}}$ & $0,06^{\mathrm{tn}}$ & $0,01^{\mathrm{tn}}$ \\
\hline $\mathrm{C}_{7}: \mathrm{C}_{2} \mathrm{X} \mathrm{C}_{3}$ & $0,54^{\text {tn }}$ & $0,00^{\mathrm{tn}}$ & $0,73^{\text {tn }}$ & $2,93^{\mathrm{tn}}$ & $1,92^{\text {tn }}$ & $1,26^{\mathrm{tn}}$ & $0,09^{\text {tn }}$ & $1,23^{\text {tn }}$ \\
\hline $\mathrm{C}_{8}: \mathrm{C}_{2} \mathrm{X} \mathrm{C}_{4}$ & $1,31^{\text {tn }}$ & $0,98^{\mathrm{tn}}$ & $\begin{array}{l}5,88^{*} \\
(0.79)\end{array}$ & $1,34^{\text {tn }}$ & $0,00^{\operatorname{tn}}$ & $0,24^{\text {tn }}$ & $0,22^{\operatorname{tn}}$ & $0,82^{\mathrm{tn}}$ \\
\hline \multicolumn{9}{|c|}{ Pengaruh waktu pada } \\
\hline $\mathrm{d} 1: \mathrm{t}_{1}$ vs $_{2} \mathrm{t}_{3}$ & - & - & $1,74^{\mathrm{tn}}$ & - & - & - & - & $4,00^{\mathrm{tn}}$ \\
\hline $\mathrm{d} 1: \mathrm{t}_{2} \mathrm{vs}_{3}$ & - & - & $0,01^{\mathrm{tn}}$ & - & - & - & - & $0,09^{\mathrm{tn}}$ \\
\hline $\mathrm{d} 2: \mathrm{t}_{1} \mathrm{vs}_{2} \mathrm{t}_{3}$ & - & - & $0,08^{\text {tn }}$ & - & - & - & - & $1,01^{\mathrm{tn}}$ \\
\hline $\mathrm{d} 2: \mathrm{t}_{2} \mathrm{vs}_{3}$ & - & - & $\begin{array}{l}9,70^{*} \\
(0,79)\end{array}$ & - & - & - & - & $0,00^{\mathrm{tn}}$ \\
\hline $\mathrm{d} 3: \mathrm{t}_{1} \mathrm{vs}_{2} \mathrm{t}_{3}$ & - & - & $3,10^{\text {tn }}$ & - & - & - & - & $0,78^{\text {tn }}$ \\
\hline $\mathrm{d} 3: \mathrm{t}_{2} \mathrm{vs} \mathrm{t}_{3}$ & - & - & $0,17^{\mathrm{tn}}$ & - & - & - & - & $1,05^{\text {tn }}$ \\
\hline $\mathrm{d} 4: \mathrm{t}_{1} \mathrm{vs}_{2} \mathrm{t}_{3}$ & - & - & $1,00^{\operatorname{tn}}$ & - & - & - & - & $0,11^{\mathrm{tn}}$ \\
\hline $\mathrm{d} 4: \mathrm{t}_{2}$ vs $\mathrm{t}_{3}$ & - & - & $1,49^{\operatorname{tn}}$ & - & - & - & - & $0,26^{\mathrm{tn}}$ \\
\hline \multicolumn{9}{|c|}{ Pengaruh dosis pada } \\
\hline t1 : D Linear & - & - & $4,05^{\text {tn }}$ & - & - & - & - & $0,16^{\text {tn }}$ \\
\hline t1 : D Kuadratik & - & - & $0,32^{\mathrm{tn}}$ & - & - & - & - & $1,35^{\mathrm{tn}}$ \\
\hline t2 : D Linear & - & - & $2,17^{\mathrm{tn}}$ & - & - & - & - & $5,57^{*}$ \\
\hline t2 : D Kuadratik & - & - & $0,01^{\mathrm{tn}}$ & - & - & - & - & $9,97^{*}$ \\
\hline t3 : D Linear & - & - & $0,19^{\mathrm{tn}}$ & - & - & - & - & $4,91^{*}$ \\
\hline t3 : D Kuadratik & - & - & $11,06^{*}$ & - & - & - & - & $3,52^{\mathrm{tn}}$ \\
\hline
\end{tabular}

F Tabel $0,05=4,30$

Keterangan: TT (tinggi tanaman), JD (jumlah daun), BKB (bobot kering brangkasan), PT (panjang tongkol), DT (diameter tongkol), BBPT (bobot biji per tongkol), B100 (bobot 100 butir), Hasil (hasil), tn(tidak nyata pada $\alpha_{0,05}$ ), * (nyata pada $\alpha_{0,05}$ ), dan angka-angka dalam kurung merupakan selisih antar perlakuan. 


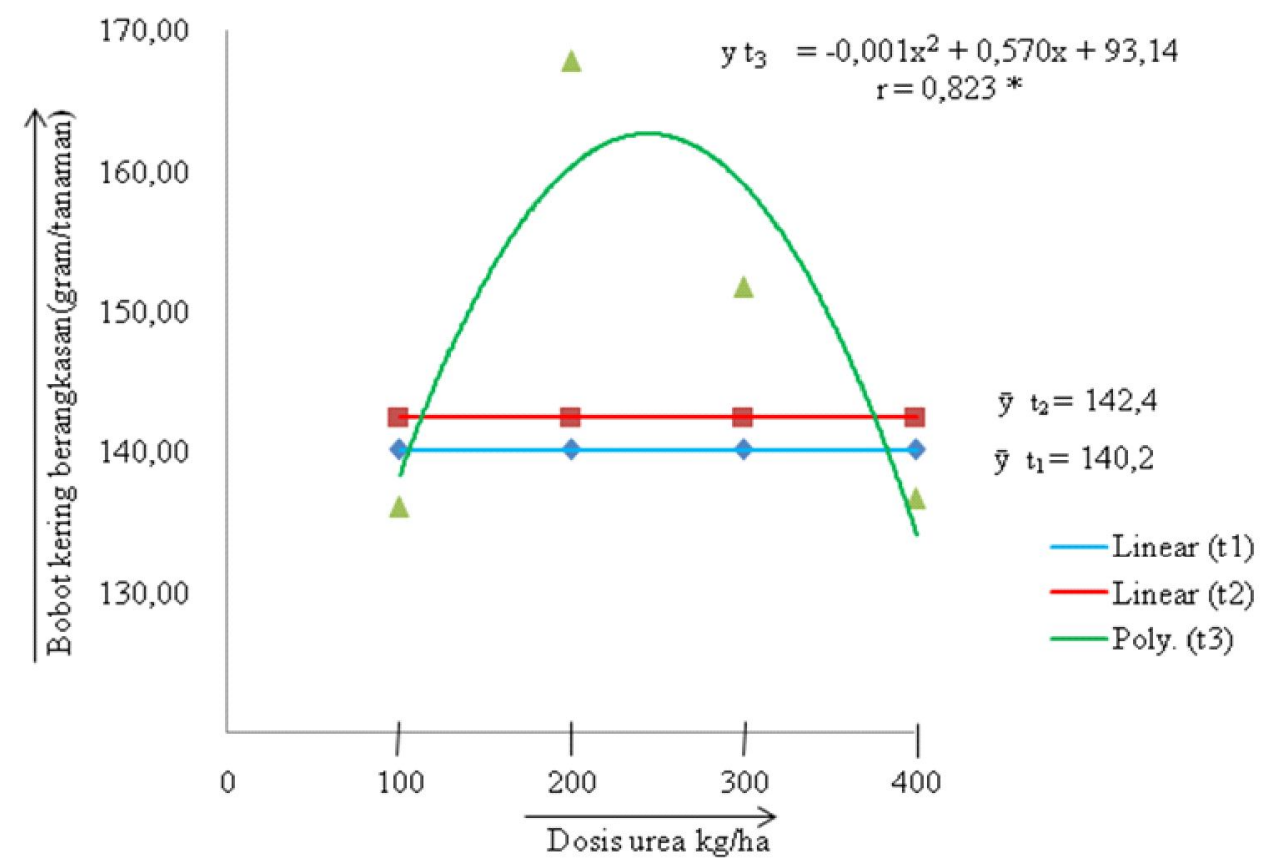

Gambar 1. Hubungan antara dosis Urea dengan bobot kering tanaman pada beberapa aplikasi pupuk.

Tabel 2. Korelasi antarvariabel pengamatan

\begin{tabular}{lcccccccc}
\hline Pengamatan & TT & JD & BKB & PT & DT & BT & B100 & HP \\
\hline HP & 0,189 tn & $-0,210$ tn & 0,241 tn & 0,348 tn & $0,654 *$ & 0,127 tn & 0,438 tn & 1,000 \\
B100 & $-0,050$ tn & 0,035 tn & 0,144 tn & 0,342 tn & 0,448 tn & $-0,088$ tn & 1,000 & \\
BT & 0,089 th & 0,308 tn & 0,320 tn & 0,173 tn & 0,205 tn & 1,000 & & \\
DT & 0,113 tn & 0,025 tn & 0,117 tn & 0,433 tn & 1,000 & & & \\
PT & 0,106 tn & 0,262 tn & 0,264 tn & 1,000 & & & & \\
BKB & 0,330 tn & 0,354 tn & 1,000 & & & & & \\
JD & 0,224 tn & 1,000 & & & & & & \\
TT & 1,000 & & & & & & & \\
\hline
\end{tabular}

Keterangan: TT (tinggi tanaman), JD (jumlah daun), BKB (bobot kering brangkasan), PT (panjang tongkol), DT (diameter tongkol), BT (Bobot biji per tongkol B100), B100 (bobot 100 butir), HP (hasil per ha), tn(tidak nyata pada $\left.\alpha_{0,05}\right)$, dan $*$ (nyata pada $\alpha_{0,05}$ ).

pemberiannya akan menyebabkan $\mathrm{N}$ yang diberikan langsung diserap oleh tanaman.

\section{KESIMPULAN}

Berdasarkan penelitian yang telah dilakukan, dapat disimpulkan bahwa waktu aplikasi urea yang diberikan secara bertahap hanya dapat meningkatkan tinggi tanaman. Pemberian urea 3 dan 4 kali lebih baik dibandingkan pemberian 2 kali. Pemberian dosis $285 \mathrm{~kg}$ urea/ha mampu meningkatkan bobot kering berangkasan. Pemberian dosis $100 \mathrm{~kg}$ urea/ha dengan aplikasi 2 kali (1 MST dan awal berbunga) sudah meningkatkan hasil jagung sebesar 10,65 $\mathrm{t} \mathrm{ha}^{-1}$.

\section{DAFTAR PUSTAKA}

Bara dan Chozin. 2009. Pengaruh dosis pupuk kandang dan frekuensi pemberian pupuk urea terhadap pertumbuhan dan produksi jagung (Zea mays. L) di lahan kering. Makalah Seminar Departemen Agronomi dan Hortikultura. Fakultas Pertanian, Institut Pertanian Bogor. Hlm 7. 


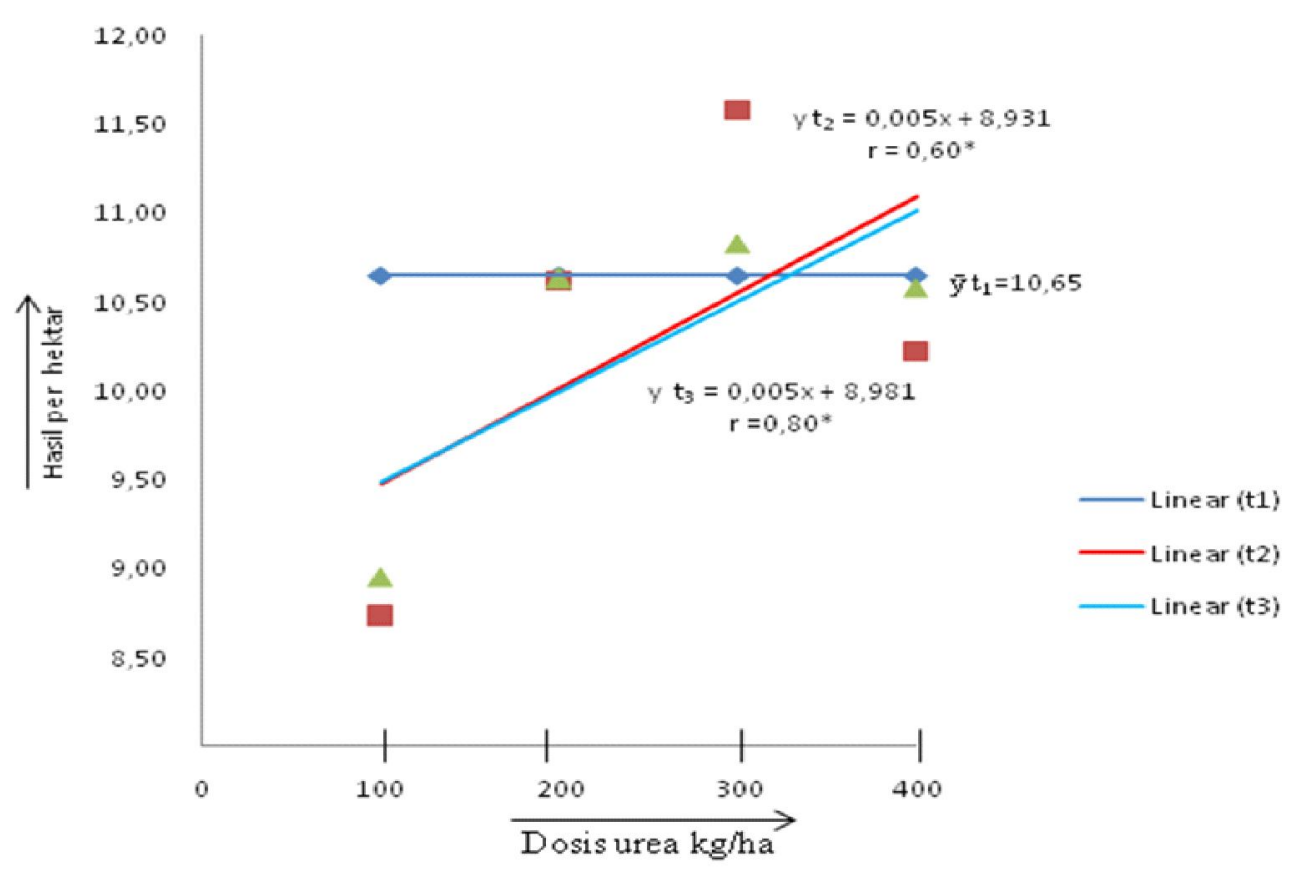

Gambar 2. Hubungan antara dosis urea dengan hasil jagung per hektar pada beberapa aplikasi pupuk.

Gardner, F. P., R. B. Pearce dan R. L. Mitchell. 1991. Fisiologi Tanaman Budidaya (Terjemahan Herawati Susilo). Universitas Indonesia Press, Jakarta.428p.

Koswara. J., 1983. Jagung. Jurusan Agronomi. Fak. Pertanian IPB, Bogor. 50 hal.

Lingga, P dan Marsono. 2008. Petunjuk Penggunaan Pupuk. Penebar Swadaya. Jakarta. 150 hal.

Mimbar, S. M. 1990. Pola Pertumbuhan dan Hasil Jagung Kretek Karena Pengaruh Pupuk N. Jilid 2. 167 hlm.

Nasution, H.S. 1994. Pengaruh Pemberian Pupuk Daun dan Berbagai Dosis $N$ terhadap
Pertumbuhan dan Produksi Jagung Manis. Skripsi. Universitas Lampung. Bandar Lampung. $70 \mathrm{hlm}$.

Salisbury, F.B., dan C.W. Ross. 1992. Fisiologi tumbuhan. Diterjemahkan Diah Lukman dan Sumaryono dari Plant Physiology. Penerbit ITB Bandung. 1995. jilid 2. $167 \mathrm{hlm}$.

Suwardi dan Roy Efendi. 2009. Efisiensi Penggunaan Pupuk $N$ pada Jagung Komposit Menggunakan Bagan Warna Daun. Balai Penelitian Tanaman Serelia. $115 \mathrm{hlm}$.

Soetoro, Yoyo S, dan Iskandar. 1988. Budidaya Tanaman Jagung. Balai Penerbit Tanaman Pangan : Bogor. $76 \mathrm{hlm}$. 